\title{
Young Generation and Future Leadership: Learn from now for Better Tomorrow
}

\author{
Kama Abdul Hakam \\ Universitas Pendidikan Indonesia \\ kama.ahakam@upi.edu \\ Ratna Fitria \\ Universitas Pendidikan Indonesia
}

\author{
Siti Nurbayani \\ Universitas Pendidikan Indonesia
}

Fajar Nugraha Asyahidda

Universitas Pendidikan Indonesia

\begin{abstract}
Indonesia's young generation is the generation that will be able to lead the nation in the future. Leadership in the future depends on the understanding of the younger generation about forms of leadership. However, today's young generation has been much affected by the times and technology is a bit much to change the mindset of the younger generation to lead the force. In addition, the views of young generation against the current leadership style are feared will change the leadership style in the future. For example, the leadership style of Governor of DKI Jakarta Basuki Tjahaja Purnama a.k.a Ahok, known as "cowboy" leadership style and its feared to be an inspiration for young generation in the lead. To that end, this article tries to give exposure of the research results conducted through quantitative methods related to the current leadership style by taking the example Basuki Tjahaja Purnama or Ahok as an example of a phenomenal leader and hoped articles can give you an idea how the shape of the future leadership expected by society.
\end{abstract}

Key Words-Young Generation, Leadership Style, Future Leadership

\section{INTRODUCTION}

Indonesian has entered the 21 st century, the century which everything has been affected by technology, the presence of technology in the midst of Indonesia peoples provide a new atmosphere for interact. The interaction that used to only be done by face to face but now can be done by using a device that is supported by applications to communicate over long distances, known as social media. The presence of social media has given big changes about how we interact and communicate. [1] Communication style that has many changes bring big impact against the perspective of people in response to the social phenomena is no exception at the point of view of society towards politics.

Through the rapid growth of technology in the form of social media, the Indonesian people are given more space to express their views on the phenomenon of politics and government. The situation is based on the Indonesian government system that embraces the democratic system rolled in 1999, through the system of society has a big hand in choosing and determining who becomes leader of the community are also given the freedom to voice their opinions against the ongoing of government. [2] Democracy in Indonesia increasingly felt by the presence of technology in the form of social media, because now anyone at any time easily get the related information policy and government policy.

The existence of technology and social media in coloring politics and government in Indonesia can be seen as a challenge and an opportunity for the nation's progress. These challenges may be criticism of a sense of community dissatisfaction against some government policies are expressed through social media and not infrequently the criticism can be ended by either cyber violence and real violence. [3] As for the great opportunities brought by technology in the form of social media is an opportunity to rally support by leveraging social media (twitter, Instagram, facebook, etc.), to galvanize support in this way is considered very effective for measuring the level of achievement of government programs, as well as support in his re-election in The next period.

The use of social media in mobilizing support for the government were based on the government's ability to interpret all forms of activities and programs that are running in the form of images or words which are uploaded to social media. [4] Today, most highlighted of a system of government is the figure of the leader. Neither the president, governors, mayors or regents. Therefore, today's leaders must be able to combine form charismatic leadership, ransformation as well transactional. [5] In addition, with the development of social media in the political sphere may indirectly increase the community's understanding of the intent and purpose of government programs that are running.

Talking about the use of social media to support the government we can see from the support given to the Governor of DKI Jakarta through movement named "Teman Ahok"(The friend of Ahok) The movement seeks to collect 1 million identity cards of Jakarta citizens as a form of support for re-election Basuki Tjahaja Purnama a.k.a Ahok in Jakarta governor election in 2017. This form of support is based on Election Commission Regulation No. 92015 about individual candidates or independent. [6] "Teman Ahok" as a volunteer trying to collect 1 million identity cards of Jakarta 
citizens as the real action in supporting Ahok for returned as the Governor of DKI Jakarta period 2017 - 2022. [7]

The forms of support as it showing that leadership of Basuki Tjahaja Purnama (Ahok) in leading Jakarta is still urgently needed by citizens, in addition Ahok lately been supported by some political parties even though there are many pros and cons. However, the probe of the forms of support shown "Teman Ahok" and political parties, the people of Indonesia as faced with two views are contradictory, views on the basis of the news about Ahok in the lead, it is not uncommon Ahok out the words that should not be spoken by a leader. The temperament can be interpreted as a violation of ethics in communication. But, on the other hand Ahok speaking style does not have a relationship with ethics but with regard to etiquette problems. [8]

Ethics and etiquette is very highly regarded in the community life, especially in the attitude of a leader. because, leaders reflect the attitude of citizens. [9] Eastern or Asian nation is still famous for a nation that upholds ethical and moral, then what if the leader says is unacceptable, even though he was a leader who is honest and will be a role model for young generation [10] Through the technology in the form of social media as well as the results of research on Ahok leadership style expected to describe what kind of shape the future leadership expected by the public through the perspective given by the younger generation as the holder of a relay of leadership in the future.

\section{YouTHS AND THE FUTURE LEADERSHIP STYLE}

Leaders and leadership is always a concern, the two issues can be explored and studied through a variety of angles disciplines such as sociology, psychology, politics, anthropology, history, pedagogy and others. Leaders and leadership is also related to the science norm practice such as: ethics, philosophy of life, pedagogic and didactics. Forms of leadership in modern society must be addressed by a professional capacity in the lead. Besides, the quality of their leadership values must always be rooted in the noble values embraced by a nation. [11]

The leadership of the future must be prepared from the aspects of culture, but in the era of globalization has brought a cultural transformation toward a modern society that operates on rationality, efficiency, creativity, independence, courage, the courage of competing risk, courage is responsible, always increasing knowledge and performance, the ability of seeing the future (future oriented), openness, obedience to the law, the ethos of work, is a variety of important values that need to be developed continuously. [12]

But modern values too put forward material aspect, therefore, may need to be counterbalanced by immaterial values, for the people of Indonesia the values contained in the Pancasila, developed through a process of education on the young generation of future leaders. To the people of Indonesia, the construction of an ideal character is a character that suits the culture of our own nation. Therefore, the pattern of education and the construction of an ideal leader character should be based on values, the norms of behavior that suits the nation's view of life namely Pancasila. In essence Pancasila is a cultural concept that later became the concept of state, as the state as well as the basic outlook of the nation. With based on the Pancasila that the life of a country meant being civilized Nations. [13]

\section{RESEARCH METHOD}

The method used in the study of patterns of leadership Basuki Tjahaja Purnama are then aligned with the development of information technology-based social media is a quantitative method. The data obtained is used to address the problem in research on the idea of leadership is expected to exist in the future by taking the leadership of Governor of Jakarta, namely Basuki Tjahaja Purnama (Ahok). Reasons for using Ahok figure as an example is because Ahok form of communication with the public is considered effective in governing but also seen as controversial by many. Data collection techniques in research using probability-sampling techniques with the aim that all units of the population have an equal opportunity to be sampled. [14] So that the number of 263 samples obtained from the 1411 population. The sample is used to answer a few questions about the behavior of leaders who aspired to the younger generation through a questionnaire distributed. [15] Questions contained in the questionnaire are about the character of the leader, the nature of extraversion, openness and the consistency of leader.

\section{RESULT AND DISCUSSION}

\section{A. The Character of the Leader}

The results of data processing on the character of a leader include emotional intelligence, friendly, confident, forthright, responsible, energetic and ethical. Aspects leader's character can be seen from the following diagram:

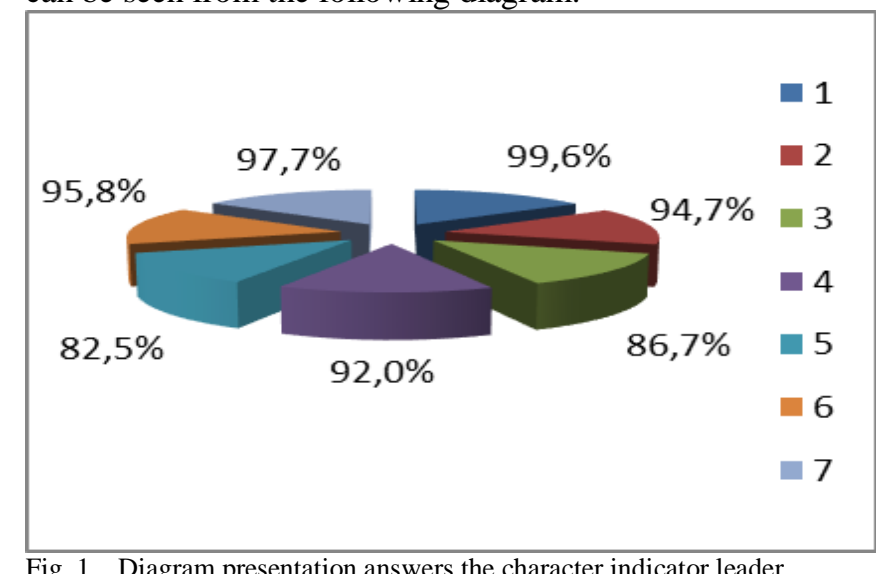

Fig. 1. Diagram presentation answers the character indicator leader

Figure 1 shows that $99.6 \%$ of younger generation wants their leader was honest. $94.7 \%$ of young generation wants their leader was friendly. $86.7 \%$ of young generation wants their outspoken leader, $92 \%$ want their leaders to be good at talking. $82.5 \%$ a leader must be energetic, they must be ethical leaders 95.8, and finally $97.7 \%$ younger generation wants their leaders have Emotional Intelligence. 


\section{B. The Nature of Extraversion}

The results of the processing of data on the nature of extraversion include intelligence, are capable of respecting the ideas of subordinates, have respect for subordinate feelings, pay attention to the fun, gregarious, active. Aspects of the nature of the extraversion leader can be seen from the following chart:
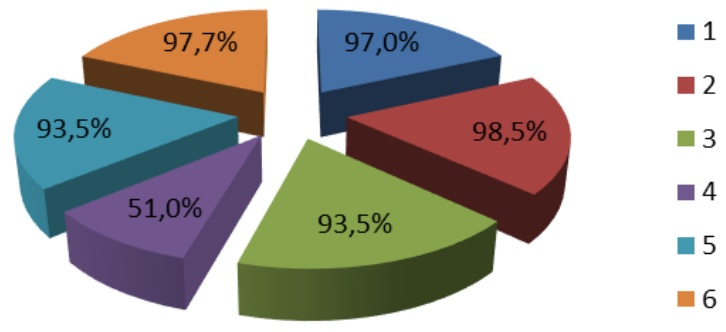

Fig. 2. Diagram presentation answers the character indicator leader

Of the 263 respondents said that $97 \%$ of the younger generation wants leaders of an intelligent, $98.5 \%$ of the younger generation wants leaders capable of respecting the ideas of subordinates, $88.5 \%$ of the younger generation wants leaders to have respect for the feelings of the subordinate, $51 \%$ of the younger generation wants leaders capable of paying attention to the pleasure of subordinates, $88.5 \%$ according to a younger generation of leaders must be a gregarious and $60.7 \%$ of the younger generation wants leaders of an active.

C. openness

The results of the processing of data about the nature of openness include tolerance, mutual trust, the welfare of subordinates, pay attention to the status of the subordinate, creative, empathetic, flexible. Aspects of the nature of openness of a leader can be seen from the following chart:
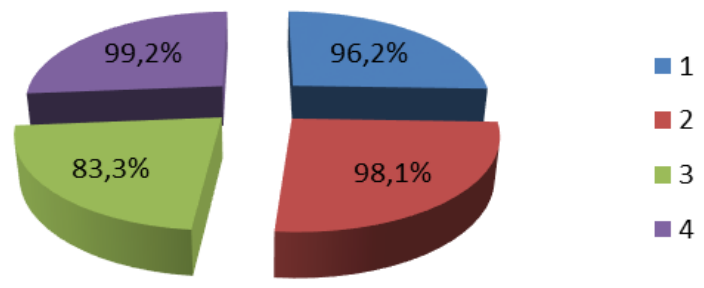

Fig. 3. Diagram presentation answers the character indicator leader

Based on these data it can be known that $88.5 \%$ of the younger generation expects of its leaders have tolerance, 97\% expect leaders to trust subordinates, neither the opposite. $92 \%$ wanted leaders are able to pay attention to the welfare of subordinates, $51.7 \%$ a leader should pay attention to the status of the subordinate, $44.5 \%$ a leader has to be creative. $88.5 \%$ of a leader should be someone who has the attitude of empathy, and $92.8 \%$ wanted a flexible leadership.

D. The Consistency of Leader

The results of data processing on consistency leaders include discipline and keep commitments. Aspects of openness of a leader can be seen from the following diagram:

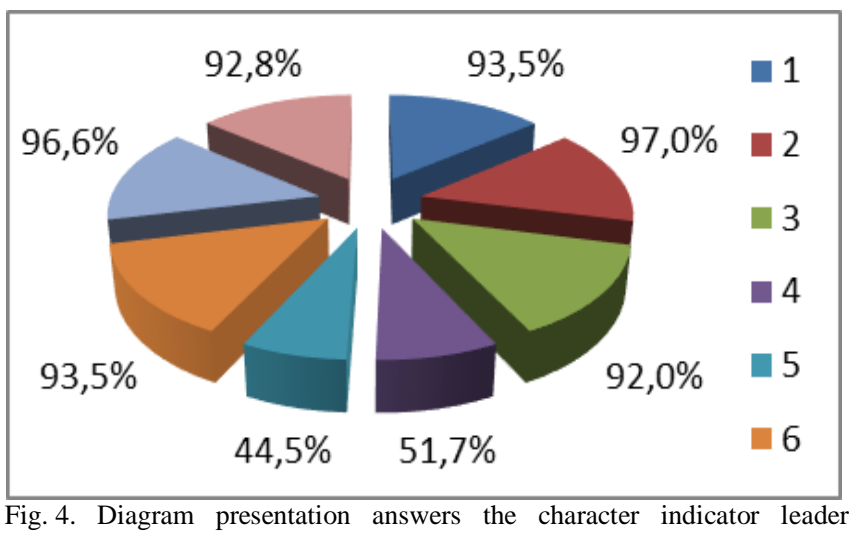

Based on these data it can be seen that the younger generation wants its leader someone who is good at putting their subordinates as its commitment by $96.2 \%$. $98.1 \%$ of the younger generation wants a leader who is consistent with what he promised, $83.3 \%$ want their openness to the subordinate leaders for leadership is held, and $99.2 \%$ want a leader who disciplined.

\section{CONCLUSION}

Being a leader is not easy, especially when faced with the progress of time and the onslaught of information technology, where information technology is a new chapter in the challenge of governance. However, good governance is a government that is able to combine ideas with the progress of time. The young generation as a generation of future leaders must have the skills of leadership that was expected in the future. Through the results of these studies show that emotional intelligence in the lead is absolutely necessary, and then the leaders of the future must be able to respect and trust the ideas provided by subordinates. On the other hand, a disciplined leader to lead a government until whenever absolutely owned in the soul of a leader.

\section{REFERENCE}

[1] Stoller E, Ed IH. Our Shared Future : Social Media , Leadership , Vulnerability, and Digital Identity. 2013;14(1):5-10.

[2] Luebke V. The Politics of Reform: Political Scandals ,. Curr Southeast Asian Aff. 2010;29(1):79-94.

[3] Linders D. From e-government to we-government: Defining a typology for citizen coproduction in the age of social media. Gov Inf Q [Internet]. Elsevier Inc.; 2012;29(4):446-54. Available from: http://dx.doi.org/10.1016/j.giq.2012.06.003

[4] Bertot JC, Jaeger PT, Grimes JM. Using ICTs to create a culture of transparency: E-government and social media as openness and anticorruption tools for societies. Gov Inf Q [Internet]. Elsevier B.V.; 2010;27(3):264-71. Available http://dx.doi.org/10.1016/j.giq.2010.03.001

[5] Sweetser KD, Kelleher T. Short Communication A survey of social media use, motivation and leadership among public relations practitioners. Public Relat Rev. 2011;37:425-8.

[6] Peraturan Komisi Pemilihan Umum. 2015.

[7] Sandi K. Teman Ahok. 2016. p. 8-10.

[8] Ngorang P. Etiket Komunikasi Politik Gubernur DKI Jakarta , Basuki Tjahaja Purnama Political Communication Ethics Jakarta. J Kaji Polit dan Masal Pembang. 2016;12(01):1793-808.

[9] Stogdill RM. Personal Factors Associated with Leadership: A Survey of the Literature. J Psychol. 1948;25(August 2013):35-71.

[10] Prasetyo D. PERSEPSI MASYAKARAT DKI JAKARTA TERHADAP FIGUR DAN KOMUNIKASI POLITIK BASUKI 
TJAHAJA PURNAMA (AHOK) Danny Prasetyo. POLITIKA. 2014;5(2).

[11] Winarni, F. 2006. Reorientasi Pendidikan Nilai dalam Menyiapkan Kepemimpinan Masa Depan. Jurnal Cakrawala Pendidikan : 139-171

[12] Dwiyanto, Agus. 2005. Mewujudkan Good Governance, Yogyakarta : Gajahmada University Press.

[13] Hakam K.A. 2008.Pendidikan Nilai. VP.Value Press. Bandung
[14] Bungin,B. 2011. Metodologi Penelitian Kuantitatif. Jakarta: Kencana Prenada Media Group.

[15] Malihah, Elly, and Siti Nurbayani. "Teaching Conflict Resolution through General Education at University: Preparing Students to Prevent or Resolve Conflicts in a Pluralistic Society." Asian Social Science 11.12 (2015): 353. 